\title{
PENGARUH PEMBERIAN AIR REBUSAN DAUN SIRSAK (Annona muricata $L$ ) TERHADAP PENURUNAN KADAR ASAM URAT PADA PASIEN RAWAT JALAN DI PUSKESMAS PASAWAHAN
}

\author{
Nela Nursoleha' ${ }^{1}$ Ahmad Yani ${ }^{2 *}$, Restu Amalia Hermanto ${ }^{3}$ \\ 1,2,3Sekolah Tinggi Ilmu Kesehatan Holistik
}

*Korespondensi: Jl. Veteran No. 272 Ciseureuh Purwakarta, Email: ahmadyani@holisticindonesia.com

\begin{abstract}
ABSTRAK
Latar Belakang: Asam urat merupakan suatu penyakit karena kelainan metabolisme purin (Hiperurisemia). Peningkatan produksi asam urat terjadi akibat : produksi asam urat berlebih, konsumsi bahan makanan yang mengandung tinggi purin, kurang cairan dan aktifitas fisik. Daun sirsak memiliki senyawa acetogenin dan flavonoid yang membantu mencegah terjadinya pembentukan asam urat.

Metode: Penelitian ini merupakan penelitian pra eksperimen dengan rancangan penelitian One group pre-post test design dengan subjek sebanyak 31 pasien rawat jalan Puskesmas Pasawahan Kabupaten Purwakarta, kadar asam urat diukur pada awal penelitian (pre-test), lalu pasien diberi treatment air rebusan daun sirsak. Air rebusan daun sirsak terdiri dari 6 gram atau 10 lembar daun sirsak yang telah dicuci bersih dan direbus dengan air $600 \mathrm{ml}$ yang dimasak hingga mendidih dan tersisa $200 \mathrm{ml}$. pemberian dilakukan selama 7 hari berturut-turut lalu kadar asam urat diukur kembali di hari ke-8 (post-test). Analisis data yang digunakan yaitu Paired T-test untuk uji univariat sedangkan uji bivariat menggunakan Rank Spearman dan Pearson Product Moment.
\end{abstract}

Hasil : Rata-rata nilai kadar asam urat sebelum diberikan air rebusan daun sirsak (pre-test) adalah 7, 16 $\pm 1,25 \mathrm{mg} / \mathrm{dl}$ dan kadar asam urat setelah diberikan air rebusan daun sirsak (posttest) adalah $7,15 \pm 1,18 \mathrm{mg} / \mathrm{dl}$.

Simpulan : Tidak ada pengaruh pemberian air rebusan daun sirsak (Annona Muricata L) terhadap penuruna kadar asam urat.

Kata kunci: Daun sirsak, Asam urat

\section{ABSTRACT}

Background: Gout is a disease due to abnormalities purine metabolism (hyperuricemia). Increased uric acid production results from: excessive uric acid production, consumption of foods containing high purines, lack of drinking and physical activity. Soursop leaf have acetogenin and flavonoid compounds which help prevent the formation of uric acid.

Method: This study was a pre-experimental study with a One group pre-post test design, with 31 subjects outpatients in Pasawahan Community Health Center, Purwakarta, uric acid levels were measured at the beginning of the study (pre-test), then patients were treated with soursop leaf boiled water treatment. Soursop leaf boiled water consists of 6 grams or 10 pieces of soursop leaf that have been washed clean and boiled with $600 \mathrm{ml}$ of water that was cooked to boiling and the remaining $200 \mathrm{ml}$. administration was carried out for 7 consecutive days then uric acid levels were measured again on the 8th day (post-test). Analysis of the data used is the Paired T-test for the univariate test while the bivariate test uses the Spearman Rank and Pearson Product Moment.

Results: The average value of uric acid levels before being given soursop leaf boiled water (pretest) was 7, $16 \pm 1,25 \mathrm{mg} / \mathrm{dl}$ and uric acid levels after being given soursop leaf boiled water (posttest) was $7.15 \pm 1,18 \mathrm{mg} / \mathrm{dl}$.

Conclusion: There was no effect of giving soursop leaf boiled water (Annona Muricata L) to decrease uric acid levels.

Key words: Soursop leaf, Uric acid 
Asam urat adalah hasil produksi tubuh, sehingga keberadaannya bisa normal dalam darah dan urin. Namun jika terlalu banyak mengkonsumsi makanan yang mengandung purin tinggi (seperti daging, kerang, dan jeroan seperti hati, ginjal, limpa, paru, otak) kadar asam urat dalam darah bisa meningkat. ${ }^{1}$ Penyakit asam urat atau yang dikenal dengan sebutan gout merupakan suatu penyakit karena kelainan metabolisme purin ( Hiperurisemia ). Gout merupakan penyakit metabolik saat terjadi penumpukan asam urat dalam tubuh secara berlebihan yang ditandai dengan adanya serangan berulang dari peradangan sendi yang akut, kadang disertai pembentukan tofus dan kerusakan sendi yang kronis. ${ }^{2}$

Diperkirakan bahwa radang sendi akibat gangguan asam urat terjadi pada 840 dari setiap 100.000 orang, dan mewakili sekitar 5\% dari total penyakit radang sendi. Penyakit radang sendi ini dapat dikelompokkan menjadi bentuk gout primer yang umum terjadi $(90 \%$ kasus penyakit radang sendi). Penyebabnya tidak diketahui dengan jelas, tapi diperkirakan akibat kelainan proses metabolisme dalam tubuh, tapi yang pasti ada hubungannya dengan obesitas, hipertensi, hiperlipidemia, dan diabetes mellitus. Umumnya dialami oleh laki-laki berusia lebih dari 30 tahun,sedangkan gout sekunder $(10 \%$ kasus) dialami oleh umumnya wanita setelah menopause. ${ }^{3}$

Menurut Riskesdas tahun 2007 prevalensi nasional penyakit sendi adalah $30,3 \%$, sedangkan menurut Riskesdas tahun 2013 prevalensi penyakit sendi di Jawa Barat adalah sekitar 32,1\%. Berdasarkan data yang diperoleh dari Puskesmas Pasawahan tahun 2017 ada sekitar 520 orang yang terkena asam urat, dimana setiap bulannya ada sekitar 40 orang yang melakukan pengecekan asam urat. Meningkatnya kadar asam urat disebabkan dari beberapa faktor yaitu faktor makanan tinggi purin, usia, jenis kelamin, stress, obat tertentu, faktor genetik, dan kurang cairan. ${ }^{4}$

Produksi asam urat di dalam tubuh meningkat ini merupakan penyebab karena mengkonsumsi makanan yang berkadar tinggi purin seperti daging, jeroan, bayam, kacang, kangkung, kerang, kembang kol, buncis, dan kepiting. Keadaan ini akan membuat metabolisme makanan tersebut membentuk asam urat yang akhirnya membuat tingginya kadar asam urat dalam darah. ${ }^{5}$

Asam urat yang terakumulasi dalam jumlah besar di dalam darah akan memicu pembentukan kristal berbentuk jarum. Kristal-kristal biasanya terkonsentrasi pada sendi, terutama sendi perifer (jempol kaki atau tangan). Orang yang indeks masa tubuh (IMT) berlebih (overweight) berisiko tinggi mengalami hiperurisemi. ${ }^{6}$

Bertambahnya usia semakin besar tingkat resiko seseorang untuk terkena penyakit asam urat. Lansia wanita 60\% lebih rawan terkena asam urat dibandingkan pria, hal ini di sebabkan oleh penurunan kadar hormone estrogen ketika wanita mengalami menopause. Ketika hormone estrogen berkurang dalam tubuh maka hanya tinggal sedikit hormon estrogen yang membantu pembuangan asam urat lewat urine dan dapat menyebabkan pembuangan asam urat menjadi tidak terkontrol. ${ }^{7}$

Penyakit gout memang bukan termasuk penyakit yang mematikan, tetapi jika tidak ditangani dengan benar bisa menjadi asam urat kronik dimana penderitanya akan sering sekali merasakan nyeri pada sendi. Penatalaksaan arthritis gout dapat dilakukan secara farmakologis dan non farmakologis yang bertujuan untuk mengurangi nyeri dan pembengkakan pada sendi serta menurunkan kadar asam urat dalam darah. ${ }^{8}$

Di Indonesia terdapat 30.000 spesies tanaman, dimana Sekurang-kurangnya 9.600 spesies berkhasiat sebagai obat dan kurang lebih 300 spesies digunakan sebagai bahan obat tradisional oleh industri obat tradisional 9 . Salah satu tanaman yang dapat digunakan sebagai pengobatan adalah daun sirsak. Sirsak (Annona muricata L.) adalah tanaman yang mengandung senyawa flavonoid, tanin, fitosterol, kalsium oksalat, dan alkaloid yang merupakan antioksidan. Daun sirsak (annona muricata) adalah bagian yang paling berkhasiat untuk 
pengobatan penyakit, salah satunya penyakit asam urat.

Selain kandungan antioksidan, sirsak juga mengandung senyawa alkoid isquinolin yang berfungsi sebagai analgetik kuat. Sifat anti-oksidan dapat mengurangi terbentuknya asam urat melalui penghambatan produksi enzim xantin oksidase. Sedangkan kombinasi sifat analgetik (mengurangi rasa sakit) dan anti inflamasi (anti-radang) mampu mengobati asam urat. Memang secara empiris sirsak banyak dipakai untuk mengobati asam urat, pegal, dan sakit pinggang. ${ }^{10}$

\section{METODE PENELITIAN}

Penelitian ini merupakan penelitian kuantitatif dengan desain pra eksperimental One group pre-post test design. Penelitian ini dilakukan di Puskesmas Pasawahan Kabupaten Purwakarta. Pemilihan subjek penelitian menggunakan teknik non probability sampling dengan jenis consecutive. Pengamatan ini dilakukan dengan menggunakan instrumen seperti alat GCU merk Easy Touch, kuesioner untuk mengetahui identitas responden, formulir FFQ Semi Quantitative, formulir untuk memantau kadar asam urat pada pre dan post test, dan software Nutrisurvey 2007 untuk menganalisis asupan purin. Proses pengambilan data dilakukan setelah subjek menandatangani informed consent. Analisis data dibagi menjadi dua yaitu analisis univariat dan analisis bivariate. Analisis univariat untuk menggambarkan karakteristik pada variabel yang diteliti. Analisis bivariat untuk melihat pengaruh diantara variabel bebas dan variabel terikat dengan uji Paired T-test.

\section{HASIL PENELITIAN}

\section{Gambaran Umum Penelitian}

Penelitian ini dilakukan bertujuan untuk mengetahui pengaruh pemberian air rebusan daun sirsak terhadap penurunan kadar asam urat pada pasien rawat jalan di wilayah Puskesmas Pasawahan Kabupaten Purwakarta. Populasi pada penelitian ini diperoleh dari data di bagian laboratorium Puskesmas Pasawahan yang rutin menjalani rawat jalan selama 1 bulan terakhir dan sudah didiagnosa asam urat setelah melakukan pengecekan di laboratorium Puskesmas Pasawahan. Pada penelitian ini subjek penelitian yang telah bersedia dan telah mengikuti tahapan penelitian dengan mengisi inform consent adalah 31 orang. Selama penelitian tidak ada subjek penelitian yang drop out atau mengundurkan diri.

Pengambilan data dilakukan dengan melakukan pengecekan kadar asam urat pada subjek penelitian secara langsung yang dilakukan oleh Analis Puskesmas Pasawahan. Kemudian peneliti menjelaskan tentang maksud penelitian ini yaitu memberikan air rebusan daun sirsak sebanyak $200 \mathrm{ml}$ selama 7 hari secara berturut-turut dan kesediaanya menjadi responden dengan menandatangani inform consent yang sudah dibuat oleh peneliti.

Setelah dua hari sebelum melakukan treatment, peneliti mengunjungi rumah subjek penelitian untuk diwawancarai terkait asupan purin menggunakan $F F Q$ Semi Quantitative.Setiap pagi peneliti mengantarkan air rebusan daun sirsak ke setiap rumah subjek penelitian selama 7 hari secara berturut-turut. Setelah diberikan treatment, dihari ke-8 dilakukan kembali pengecekan kadar asam urat pada subjek penelitian secara langsung yang dilakukan oleh enumerator yang terlatih dengan cara mengunjungi tempat tinggal subjek penelitian.

\section{Karakteristik Subjek Penelitian}

Karakteristik subjek penelitian pada penelitian ini terdiri atas jenis kelamin, asupan kadar purin, kadar asam urat sebelum dan setelah treatment. Berdasarkan tabel 4.1 diketahui bahwa angka penderita asam urat pada perempuan $(87,1 \%)$ lebih tinggi dari pada laki-laki $(12,9 \%)$. Subjek penelitian yang memiliki tingkat pendidikan tinggi $12,9 \%$, nilai pendidikan menengah $45,2 \%$ dan yang memiliki nilai pendidikan dasar 41,9\%. Dilihat dari kadar asam urat sebelum treatment $100 \%$ responden memiliki kadar asam urat yang tinggi sedangkan kadar asam urat setelah treatment 16,1\% 
mengalami penurunan. Subjek penelitian $64,5 \%$ berusia diatas 50 tahun. yang berusia $30-50$ tahun $35,5 \%$ dan

Tabel 1 Distribusi Frekuensi Karakteristik Subjek Penelitian

\begin{tabular}{lcc}
\hline Variabel & N & \% \\
\hline Jenis Kelamin & & \\
Laki-Laki & 4 & 12,9 \\
Perempuan & 27 & 87,1 \\
\hline Kadar Asupan Makanan Yang & & \\
Mengandung Kadar Purin Tinggi & & \\
Rendah ( $<500 \mathrm{mg}$ ) & 22 & 71,0 \\
Normal ( 500-1000 mg) & 8 & 25,8 \\
Tinggi (> 1000 mg) & 1 & 3,2 \\
\hline Tingkat Pendidikan & & \\
Dasar & 13 & 41,9 \\
Menengah & 14 & 45,2 \\
Tinggi & 4 & 12,9 \\
\hline Kadar Asam Urat Sebelum Treatment & & \\
Normal & - & - \\
Tinggi & 31 & 100 \\
\hline Kadar Asam Urat Setelah Treatment & & \\
Normal & 5 & 16,1 \\
Tinggi & 26 & 83,9 \\
\hline Usia & & \\
30-50 tahun & 11 & 35,5 \\
$>50$ tahun & 20 & 64,5 \\
\hline
\end{tabular}

Pengaruh Pemberian Air Rebusan Daun Sirsak Terhadap Penurunan Kadar Asam
Urat Pada Pasien Rawat Jalan Puskesmas Pasawahan Kabupaten Purwakarta

Tabel 2 Pengaruh Pemberian Air Rebusan Daun Sirsak Terhadap Penurunan Kadar Asam Urat

\begin{tabular}{|c|c|c|c|c|c|}
\hline Variabel & $N$ & Pre-test & & Post-test & \\
\hline Kadar Asam Urat & & Mean $\pm S D$ & 31 & Mean \pm SD & $0968^{*}$ \\
\hline
\end{tabular}

Berdasarkan tabel 2 diperoleh nilai $p$ value pada variabel kadar asam urat sebesar 0, 968 ( $p>0,05)$ sehingga dapat disimpulkan bahwa tidak ada pengaruh pemberian air rebusan daun sirsak terhadap penurunan kadar asam urat pretest dan post-test pada penderita asam urat.

Hubungan Kadar Asam Urat Sebelum Dan Setelah Treatmen Dengan Asupan Makanan Yang Mengandung Tinggi Purin

Tabel 3 Hasil Uji Hubungan Kadar Asam Urat Sebelum Dan Setelah Treatmen Dengan Makanan Yang Mengandung Kadar Purin Tinggi

\begin{tabular}{|c|c|c|c|c|}
\hline Variabel & \begin{tabular}{|l|} 
Kadar asam \\
urat Pre-test \\
Mean \pm SD \\
\end{tabular} & $P$ & $\begin{array}{l}\text { Kadar asam urat } \\
\text { Post-test } \\
\text { Mean } \pm \text { SD } \\
\end{array}$ & $P$ \\
\hline & $7,16 \pm 1,25$ & \multirow[t]{2}{*}{$0,435^{a}$} & $7,15 \pm 1,18$ & \multirow[t]{2}{*}{$0,386^{b}$} \\
\hline $\begin{array}{l}\text { Makanan Yang } \\
\text { Mengandung Kadar Purin } \\
\text { Tinggi }\end{array}$ & $408 \pm 260$ & & $2,52 \pm 0,27$ & \\
\hline
\end{tabular}


Berdasarkan tabel 3 diperoleh nilai $p$ value 0,435 ( $p>0,05$ ) Sehingga dapat disimpulkan bahwa tidak ada hubungan antara kadar asam urat sebelum treatment dengan makanan yang mengandung kadar purin tinggi. Berdasarkan tabel 4.3 diperoleh nilai $p$ value 0,386 ( $p>0,05$ )
Sehingga dapat disimpulkan bahwa tidak ada hubungan antara kadar asam urat setelah treatment dengan asupan purin.

Hubungan Asupan Makanan Yang Mengandung Tinggi Purin Dengan Kadar Asam Urat

Tabel 4 Hasil Uji Hubungan Makanan Yang Mengandung Kadar Purin Tinggi Dengan Kadar Asam Urat

\begin{tabular}{|c|c|c|c|c|}
\hline \multirow{2}{*}{$\begin{array}{l}\text { Kadar asupan makanan yang } \\
\text { mengandung kadar purin tinggi }\end{array}$} & Pre-test & \multirow{2}{*}{$p$} & Post-test & \multirow{2}{*}{$p$} \\
\hline & Mean \pm SD & & Mean \pm SD & \\
\hline Rendah & $\begin{array}{l}408 \pm 260 \\
1,32 \pm 0,54\end{array}$ & $0,562^{*}$ & $\begin{array}{l}2,52 \pm 0,27 \\
1,32 \pm 0,54\end{array}$ & $0,252^{*}$ \\
\hline Normal & $\begin{array}{l}408 \pm 260 \\
1,32 \pm 0,54\end{array}$ & $0,599 *$ & $\begin{array}{l}2,52 \pm 0,27 \\
1,32 \pm 0,54\end{array}$ & $0,258^{*}$ \\
\hline Tingggi & $\begin{array}{l}408 \pm 260 \\
1,32 \pm 0,54\end{array}$ & - & $\begin{array}{l}2,52 \pm 0,27 \\
1,32 \pm 0,54\end{array}$ & - \\
\hline
\end{tabular}

*chi-square

Berdasarkan tabel 4.4 untuk pre-test kategori rendah diperoleh nilai $p$ value $0,562(p>0,05)$ Sehingga dapat disimpulkan bahwa tidak ada hubungan antara makanan yang mengandung kadar purin tinggi dengan kadar asam urat sebelum treatment. Berdasarkan tabel 4.4 untuk kategori normal diperoleh nilai $p$ value 0,599 ( $p>0,05)$ Sehingga dapat disimpulkan bahwa tidak ada hubungan antara makanan yang mengandung kadar purin tinggi dengan kadar asam urat sebelum treatment. Berdasarkan tabel 4.4 untuk post-test kategori rendah diperoleh nilai $p$ value $0,252(p>0,05)$ Sehingga dapat disimpulkan bahwa tidak ada hubungan antara makanan yang mengandung kadar purin tinggi dengan kadar asam urat sebelum treatment. Berdasarkan tabel 4.4 untuk kategori normal diperoleh nilai $p$ value 0,258 $(p>0,05)$ Sehingga dapat disimpulkan bahwa tidak ada hubungan antara makanan yang mengandung kadar purin tinggi dengan kadar asam urat sebelum treatment. Untuk kategori tinggi baik pada pre-test maupun post-test setelah dilakukan uji statistik nilai $p$ valuenya tidak terbaca, dikarenakan pada kategori tersebut tidak bervariasi.

\section{Frekuensi Subjek Penelitian Yang Sering Mengkonsumsi Bahan Makanan Kadar Tinggi Purin Berdasarkan FFQ Semi Quantitative}

Tabel 5 Distribusi Frekuensi Makanan Tinggi Purin Yang Sering Dikonsumsi

\begin{tabular}{cc}
\hline jenis makanan & $\%$ \\
\hline Kafein & 16,1 \\
\hline Hati Sapi & 9,7 \\
\hline Ikan sarden & 54,8 \\
\hline Kangkung & 83,9 \\
\hline Bayam & 32,3 \\
\hline Hati ayam & 54,8 \\
\hline Ikan teri & 61,3 \\
\hline Udang & 32,3 \\
\hline Biji melinjo & 32,3 \\
\hline Kacang-kacangan & 77,4 \\
\hline Ayam dengan kulit & 58,1 \\
\hline Ayam tanpa kulit & 45,2 \\
\hline
\end{tabular}




\begin{tabular}{cc}
\hline Tempe & 87,1 \\
\hline Tahu & 90,3 \\
\hline Jamur & 51,6 \\
\hline
\end{tabular}

Berdasarkan tabel 5 diketahui bahwa masih banyak subjek penelitian yang mengkonsumsi makanan berkadar purin tinggi, seperti kafein (kopi, teh dan cokelat) $16,1 \%$, hati sapi $9,7 \%$, ikan sarden $54,8 \%$, Jamur 51,6\%, kangkung 83,9\%, bayam $32,3 \%$, hati ayam $54,8 \%$, ikan teri $61,3 \%$, udang $32,3 \%$, biji melinjo $32,3 \%$, kacangkacangan $77,4 \%$, ayam dengan kulit 58,1\%, Ayam tanpa kulit $45,2 \%$, tempe $87,1 \%$, tahu $90,3 \%$ dan kerang $25,8 \%$.

\section{PEMBAHASAN \\ Karakteristik Subjek Penelitian}

Pada hasil penelitian yang dilakukan

di Puskesmas Pasawahan berdasarkan gambaran karakteristik dari 31 orang yang diteliti ternyata 27 orang $(87,1 \%)$ berjenis kelamin perempuan dan 4 orang $(12,9 \%)$ berjenis kelamin laki-laki. Menurut Misnadiarly (2007), kadar asam urat normal pada laki-laki berkisar 3,5-7 mg/dl dan pada perempuan berkisar 2,6-6 mg/dl. Kadar asam urat di dalam darah tergantung pada usia dan jenis kelamin. Setelah pubertas, pada laki-laki kadar asam urat meningkat secara bertahap dan mencapai $5,2 \mathrm{mg} / \mathrm{dl}$. Pada perempuan kadar asam urat biasanya tetap rendah, akan tetapi ketika memasuki masa pramenopause kadarnya meningkat mendekati kadar asam urat pada laki-laki bisa mencapai $4,7 \mathrm{mg} / \mathrm{dl}$ bahkan bisa lebih. ${ }^{1}$

Asupan purin keseluruhan dari subjek penelitian rendah yaitu $<500 \mathrm{mg}$ per hari. Asupan makanan yang mengandung kadar purin tinggi, ada $25,8 \%$ dengan asupan purin normal (500-1000) mg, 71\% dengan asupan purin rendah $(<500 \mathrm{mg})$ dan $3,3 \%$ dengan asupan purin tinggi ( $>1000 \mathrm{mg}$ ).

Tingkat pendidikan yang berpendidikan dasar sebanyak 12,9\%, menengah $45,2 \%$ dan tinggi $41,9 \%$. Tidak dapat dipungkiri bahwa semakin tinggi tingkat pendidikan seseorang maka akan semakin mudah pula mereka menerima informasi dan pada akhirnya pengetahuan yang dimiliki semakin banyak. Menurut
Kusnanto (2006), bahwa pada faktor pendidikan berpengaruh pada tingkat kesehatan seseorang, subjek penelitian yang pendidikannya tinggi maka perhatian terhadap makanan lebih baik dibandingkan dengan tingkat pendidikan yang rendah. Kadar asam urat sebelum treatment 100\% subjek penelitian memiliki kadar asam urat yang tinggi sedangkan kadar asam urat setelah treatment $16,1 \%$ mengalami penurunan.

Dari hasil penelitian menunjukan data usia $>50$ tahun cenderung memiliki kadar asam urat yang tinggi yaitu 64,5\%. Menurut Ellin Puji Aprillia (2018) usia berkaitan dengan peningkatan kadar asam urat, ketika usia $>50$ tahun maka akan mengalami perubahan baik fisik, mental dan psikologis. ${ }^{11}$ Salah satu perubahan fisiknya yaitu terjadinya penurunan fungsi ginjal yang mengakibatkan peningkatan kadar asam urat akibat ginjal tidak mampu mengeluarkan purin dengan baik sehingga terjadi pengendapan purin.

\section{Pengaruh Pemberian Air Rebusan Daun Sirsak Terhadap Penurunan Kadar Asam Urat}

Rata-rata kadar asam urat pasien rawat jalan di awal pengecekan (pretest) adalah 7,16 dengan standar deviasi 1,25, sedangkan rata-rata kadar asam urat pasien rawat jalan setelah mendapatkan treatment air rebusan daun sirsak sebanyak $200 \mathrm{ml}$ selama 7 hari (posttest) adalah 7,15 dengan standar deviasi 1,18. Hasil uji statistik diperoleh $p=0,968(p>0,05)$ sehingga dapat di simpulkan bahwa tidak ada pengaruh pemberian air rebusan daun sirsak terhadap penurunan kadar asam urat pre-test dan post-test pada penderita asam urat.

Hasil penelitian ini tidak sejalan dengan penelitian yang dilakukan oleh Ilkafah (2017) Efektivitas Daun Sirsak Dalam Menurunkan Nilai Asam Urat Dan Keluhan Nyeri Pada Penderita Gout Di Kelurahan Tamalanrea Makasar. 
Berdasarkan hasil penelitian terhadap penderita asam urat dengan jumlah subjek pnelitian 32 orang setelah diberikan treatmen air rebusan daun sirsak mengalami penurunan. ${ }^{12}$

Hasil menunjukan hanya beberapa subjek penelitian yang mengalami penurunan pada kadar asam uratnya dikarenakan beberapa faktor seperti usia, jenis kelamin, diet purin dan pola makan. Menurunnya kadar asam urat pada subjek penelitian dikarenakan kandungan acetogenin dan flavonoid dalam daun sirsak yang dapat membantu memproduksi urine sehingga mampu mengeluarkan asam urat lebih banyak melalui urine. ${ }^{13} \mathrm{Hal}$ ini dapat digunakan sebagai salah satu terapi nonfarmakologi yang dapat dilakukan untuk menurunkan kadar asam urat. Pemberian air rebusan daun sirsak digunakan dalam jangka panjang tanpa menimbulkan efek samping dengan penggunaan yang benar. Khasiat yang terkandung dalam daun sirsak mempunyai beberapa senyawa-senyawa seperti minyak atsiri, tannin dan flavonoid, kandungan tersebut yang dapat menurunkan kadar asam urat dengan jalan menghambat kerja enzim xantin oksidase sehingga dapat menghambat pembentukan asam urat.

Terapi pemberian air rebusan daun sirsak merupakan terapi yang praktis dan ekonomis. Peneliti menerapkan dengan cara merebus daun sirsak yang sudah dicuci sebanyak 10 lembar atau 6 gram ke dalam air sebanyak $600 \mathrm{ml}$ selama \pm 15 menit, kemudian menjadi $200 \mathrm{ml}$, air rebusan daun sirsak diantarkan ke masing-masing ke tempat subjek penelitian tinggal untuk diminum setiap pagi setelah makan. Penelitian yang dilakukan oleh Putri Setyarini (2018) tentang Efektivitas Pemberian Rebusan Air Daun Sirsak Dan Jus Sirsak Terhadap Perubahan Kadar Asam Urat Di Wilayah Kerja Puskesmas Demangan Kota Madiun, dimana waktu pemberian air rebusan daun sirsak diberikan setiap pagi setelah makan. ${ }^{14}$

Konsumsi makanan tinggi purin memicu tingginya kadar asam urat di dalam serum. Purin sebagai senyawa awal dihasilkannya asam urat berasal dari tiga sumber yang utama yaitu diet tinggi purin, perubahan jaringan asam nukleat membentuk nukleotida purin, dan sintesis de novo dari basa purin. Asupan purin normal rentang 500-1000 mg per hari, di bawah $500 \mathrm{mg}$ per hari dikategorikan rendah dan berlebih bila di atas $1000 \mathrm{mg}$ per hari. Hasil penelitian menunjukan riwayat makan terdahulu subjek penelitian menggunakan FFQ Semi Quantitative 71\% termasuk ke dalam kategori rendah, akan tetapi setiap harinya ketika peneliti mengantarkan air rebusan daun sirsak peneliti selalu menanyakan makanan apa saja yang dikonsumsi dihari kemarin dan ternyata banyak subjek penelitian yang tidak patuh dengan diet makanan tinggi purin sehingga dalam penelitian ini sehingga 3 dari 31 subjek penelitian ada yang mengeluh merasakan pegal-pegal serta terjadinya kenaikan kadar asam urat pada saat treatment selesai (post-test).

Terjadinya peningkatan kadar asam urat ini dapat disebabkan oleh konsumsi makanan yang mengandung tinggi purin seperti daging, jeroan, bayam, kacang, kangkung, buncis dan kepiting. Makanan yang sering dikonsumsi oleh subjek penelitian adalah makanan jenis tinggi purin seperti ikan sarden 54,8\%, Jamur $51,6 \%$, kangkung 83,9\%, ikan teri 61,3 , kacang-kacangan $77,4 \%$, ayam dengan kulit $58,1 \%$, tempe $87,1 \%$ dan tahu $90,3 \%$.

Tahu dan tempe merupakan sumber protein nabati yang dikenal murah dan terjangkau oleh masyarakat. Konsumsi tahu diprediksikan sebesar 7,88 kg/kapita pada pada tahun 2017 dan terus meningkat menjadi sebesar 8,03 kg/kapita pada tahun 2019. Sementara konsumsi tempe diprediksikan sebesar 7, $40 \mathrm{~kg} / \mathrm{kapita}$ pada tahun 2017 dan terus meningkat menjadi sebesar 7, $46 \mathrm{~kg} / \mathrm{kapita}$ pada tahun 2019.15 Dikarenakan harga tempe dan tahu terjangkau, banyak orang mengkonsumsinya setiap hari tanpa memperdulikan kandungan purin, sehingga dapat menyebabkan kadar asam urat dalam darahnya tinggi.

Salah satu penyebab yang mempengaruhi kadar asam urat adalah olah raga atau aktivitas fisik. Olah raga atau 
gerakan fisik akan menyebabkan peningkatan kadar asam laktat. Asam laktat terbentuk dari proses glikolisis yang terjadi di otot. Jika otot berkontraksi didalam media anaerob, yaitu media yang tidak memiliki oksigen maka glikogen yang menjadi produk akhir glikolisis akan menghilang dan muncul laktat sebagai produksi akhir utama. Peningkatan asam laktat dalam darah akan menyebabkan penurunan pengeluaran asam urat oleh ginjal.

Cairan merupakan salah satu media pembuangan hasil metabolit tubuh, Jika seseorang mengkonsumsi cairan dalam jumlah tinggi, reabsorpsi air di ginjal menurun dan ekskresi zat terlarut air meningkat. Asupan minimal cairan lansia yaitu sebesar $1500 \mathrm{ml}$ per hari, namun kebutuhan seseorang akan air berbedabeda tergantung tingkat aktifitas fisik, suhu, lingkungan, berat badan, asupan energi dan luas permukaan badan. Penelitian yang dilakukan Ervi Diantari dkk (2013) ditemukan 2 orang subjek dengan konsumsi purin dalam jumlah yang sama, IMT hampir sama, sedangkan asupan cairan mereka berbeda, hasilnya yang mengkonsumsi cairan lebih dari $2000 \mathrm{ml}$ kadar asam uratnya rendah sedangkan yang mengkonsumsi cairan lebih rendah kadar asam uratnya tinggi. 16

\section{SIMPULAN}

Berdasarkan hasil penelitian yang dilakukan maka dapat disimpulkan bahwa Rata-rata nilai kadar asam urat sebelum diberikan air rebusan daun sirsak (pre-test) adalah 7, 16 $\pm 1,25 \mathrm{mg} / \mathrm{dl}$ dan kadar asam urat setelah diberikan air rebusan daun sirsak (post-test) adalah 7,15 $\pm 1,18 \mathrm{mg} / \mathrm{dl}$. 31 subjek penelitian $16,1 \%$ mengalami penurunan kadar asam urat meskipun tidak terlalu signifikan. Sedangkan hasil uji statistik bisa disimpulkan bahwa tidak ada pengaruh pemberian air rebusan daun sirsak terhadap penurunan kadar asam urat pada pasien rawat jalan di Puskesmas Pasawahan Kabupaten Purwakarta dengan nilai $p$ value sebesar $0,968(p>0,05)$.
1. Misnadiarly. Rematik (Asam Urat, Hiperurisemia, Arthritis Gout), Pustaka Populer Onor, Jakarta. 2007.

2. Sutanto T. Deteksi, Pencegahan, Pengobatan asam urat Yogyakarta: Buku Pintar. 2013.

3. Vindy GN. Wurangian, et al. Gambaran Asam Urat Pada Remaja Obes Di Kabupaten Minahasa. Fakultas Kedokteran Universitas Sam Ratulangi Manado. Skripsi. 2013.

4. Kemenkes RI. Riset Kesehatan Dasar Tahun 2013. Jakarta: Kementrian Kesehatan RI. 2013.

5. Anjarwati W. Tulang dan Tubuh Kita, Getar Hati, Yogyakarta. 2010.

6. Darmawan. Mencegahan dan Mengobati Asam Urat. Yogyakarta: Araska. 2008.

7. Damayanti. Panduan Lengkap Mencegah \& Mengobati Asam Urat.Yogykarta : Araska. 2013.

8. Andriani A, Chaidir R. Pengaruh pemberian air rebusan daun salam (Syzygium Polyanthum) terhadap penurunan kadar asam urat. Jurnal Ipteks Terapan. 2016.

9. Depkes RI. Profil Kesehatan 2007. Departemen Kesehtan RI. 2007.

10. Wardani RE. Pengaruh terapi jus sirsak terhadap penurunan kadar asam urat lansia wanita di desa gayaman kecamatan mojoanyar kabupaten Mojokerto.skripsi. 2015.

11. Ellin AP. Pengaruh Pemberian Air Rebusan Daun Salam Terhadap Penurunan Kadar Asam Urat Pada Lansia. Skripsi. 2018.

12. Ilkafah. Efektivitas daun sirsak dalam menurunkan nilai asam urat dan lekuhan nyeri pada penderita goutdi kelurahan tamalanrea makasar. Jurnal Ilmiah Farmasi - UNSRAT Vol. 6 No. 2. Universitas Hasanuddin. Makassar. 2017.

13. Puspitasari ML, et al. Aktivitas Antioksidan Suplemen Herbal Daun Sirsak (Annona Muricata L.) Dan Kulit Manggis (Garcinia Mangostana L.). Jurnal Pangan Dan Agroindustri Vol. 4 No 1 P.283-290. 2016.

\section{DAFTAR PUSTAKA}


14. Setyarini P. Efektivitas Pemberian Rebusan Air Daun Sirsak Dan Jus Sirsak Terhadap Perubahan Kadar Asam Urat Di Wilayah Kerja Puskesmas Demangan Kota Madiun. Jurnal Kesehatan. ISSN 1979-7621 Edisi Khusus, No. 1. Februari. 2018.

15. Buletin Konsumsi Pangan, volume 8 nomor 2, Pusat Data dan Sistem Informasi Pertanian. 2017.
16. Diantari E, et al. Pengaruh Asupan Purin Dan Cairan Terhadap Kadar Asam Urat Wanita Usia 50-60 Tahun Di Kecamatan Gajah Mungkur, Semarang.Journal of Nutrition College, Vol 2, No 1, Hlm 44-49. 2013. http://ejournal-

s1.undip.ac.id/index.php/jnc. 